\title{
8. Ecology and the Arnhem Land Expedition: Raymond Specht, a botanist in the field
}

\author{
Lynne McCarthy
}

This chapter explores the work of Raymond Specht, botanist on the 1948 American-Australian Scientific Expedition to Arnhem Land. In this chapter, I examine Specht's botanical collecting from two related perspectives. First, I consider the practical challenges of undertaking field-based plant ecology in the tropical environment of northern Australia, and second, I discuss Specht's ecological surveys (presenting a brief history of the development of ecology as a discipline) and his creation of an extensive botanical collection during eight months working in the field. The botanical collections from the Expedition illuminate Specht's training in plant ecology, and his skill, dedication and passion for field-based work. I explore how Specht's experience leading up to the Expedition affected the subsequent approach that he took to fieldwork in Arnhem Land. Specht was required to negotiate landscapes that were familiar in principle, and yet at the same time foreign to a plant ecologist from southern Australia. His botanical and plant ecology work shows how Specht had to actively adapt to, and translate, his field skills and knowledge when working in northern Australia. It is place - in this case, Arnhem Land - that is centrally implicated in the work of this botanist. Specht's reading of landscape was informed by taking a holistic approach to his fieldwork, recording accurate and detailed observations of complex Arnhem Land environments.

\section{Ecology in the Early Days}

Ecology has been described as a science of holism: an integrative science linking knowledge about the physical world with the study of living things. ${ }^{1}$ Complexity, diversity and a lack of unity have characterised ecological theory and practice since the discipline emerged during the late nineteenth and early twentieth centuries. By the 1890s, ecology was regarded as a separate field of study from biological sciences and botany. ${ }^{2}$ During the early twentieth century, the

\footnotetext{
1 Hay, P. 2002, Main Currents in Western Environmental Thought, UNSW Press, Sydney; Gibbons, W. 1993, Keeping all the Pieces: Perspectives on natural history and the environment, Smithsonian Institution Press, Washington, DC.

2 McIntosh, R. P. 1985, The Background of Ecology: Concept and Theory, Cambridge University Press, UK.
} 
discipline began to address broader questions about the relationships between living things and their environment. ${ }^{3}$ Field studies were seen as essential to the practice of ecology, and early ecologists generally followed a holistic philosophy in the study of landscapes and dynamics of plant communities. ${ }^{4}$ The concept of ecosystem has changed in character over time within this discipline, with a shift of emphasis from 'place' and 'organism' to 'flux' and 'process'. ${ }^{5}$ Specht's work on the Arnhem Land Expedition in 1948 reflects this earlier concept of ecosystem. Eliciting and understanding connections and relationships between place and diverse plant communities across Arnhem Land were his primary goals.

Trends in the development of the discipline of ecology in American, British and Australian contexts are pertinent to understanding the approach and techniques used for Specht's botanical and plant ecology work on the Arnhem Land Expedition. Frederic Clements forged the discipline of ecology in the United States of America in the 1890s, with attention to the development of the concept of a plant community as both a dynamic and a complex entity interacting with its environment. ${ }^{6}$ Clements set the tone for ecological research among American botanists for approximately 40 years. British thinking on the discipline of ecology began with regional surveys of plants in the landscape, creating a systematic overview. This was further developed towards a focus on understanding patterns between different plant communities - akin to the American concept of dynamic communities. Ecology in Australia was influenced by American and British scientific thinking, emerging as a discipline of science in the 1920s. ${ }^{7}$ It was initially regarded as a 'science of exploration', a key to understanding new lands. ${ }^{8}$

The Botany Department at the University of Adelaide played a leading role in plant ecology research in Australia, particularly focusing on interactions of plant communities with the environment. Head of Department, Professor Joseph Wood, encouraged his staff and students to develop experimental research on the taxonomy (classification and naming of plants), ecology, and distribution patterns of plant communities, emphasising the importance of fieldwork as part of any ecological research. This approach to ecological studies was instilled in

\footnotetext{
3 Kingsland, S. 1993, 'An elusive science: ecological enterprise in the southwestern United States', in M. Shortland (ed.), Science and Nature: Essays in the history of the environmental sciences, British Society for the History of Science Monographs 8, Oxford, pp. 151-79.

4 Bowler, P. 1993, 'Science and the environment: new agendas for the history of science?', in Shortland, Science and Nature, pp. 1-21.

5 Allen, T. F. and Roberts, D. W. 1997, 'Foreword', in R. Ulanowicz (ed.), Ecology, The Ascendant Perspective, Columbia University Press, New York, pp. xi-xiii.

6 Nicolson, M. 1988, 'No longer a stranger? A decade in the history of ecology', History of Science, vol. 26, no. 72, pp. 183-200; Kingsland, 'An elusive science', pp. 151-79.

7 Robin, L. R. 1998, Defending the Little Desert: The rise of ecological consciousness in Australia, Melbourne University Press, Carlton, Vic

8 Robin, L. R. 1997, 'Ecology: a science of empire?', in T. Griffiths and L. R. Robin (eds), Ecology and Empire: Environmental history of settler societies, Melbourne University Press, Carlton, Vic., pp. 63-75.
} 
Raymond Specht, a student in this department. As a second-year undergraduate in 1944, Specht gained experience as a field botanist by conducting a plantcollecting field trip for assessment. He travelled from Adelaide to Whyalla and Iron Knob via the lower Flinders Ranges in South Australia. One hundred plant specimens were collected, dried, pressed, identified, and prepared for the Adelaide Herbarium. ${ }^{9}$ The most formative year of Specht's time in the Botany Department was his honours year in 1946 and work on the ecological survey of $260 \mathrm{sq} \mathrm{km}$ of the Adelaide Hills. Travelling on foot and by bicycle, he investigated distribution patterns of different eucalypt species in the landscape, which led to his lifelong study and interest in the structure, growth and biodiversity of ecosystems and plant communities (see Specht, this volume). These experiences as a field ecologist in southern Australia provided Specht with methods and techniques that he would soon draw upon when he joined the Arnhem Land Expedition as a botanist.

\section{Specht's Recruitment to the Arnhem Land Expedition}

The 1948 Arnhem Land Expedition was jointly sponsored by the National Geographic Society, the Smithsonian Institution and Australia's Department of Information. The Expedition party was eight months in the field, collecting more than 25 tonnes of specimens, which were intended as important contributions to science. Expedition members included people from the disciplines of archaeology, anthropology, ichthyology, ornithology, nutrition and medical sciences, and botany, as well as photographers and filmmakers (see May, this volume). The leader, Charles Mountford, reported that no previous scientific expedition in Australia had covered so many interlocking fields of natural history, medical science and ethnology. ${ }^{10}$

The Australian Government intended that the Expedition would generate large amounts of scientific and general information, provide a record of Aboriginal people in story, photograph and film, and provide favourable publicity for the nation. It would also foster good relations with the United States, and stimulate scientific cooperation between the two countries (see Beazley, this volume). ${ }^{11}$

Raymond Specht was initially invited to be part of the Arnhem Land Expedition in September 1946:

9 Specht, R. L. n.d., The development of environmental science policy in Australia, Unpublished manuscript. 10 Specht, R. L., in C. P. Mountford (ed.) 1956, Records of the American-Australian Scientific Expedition to Arnhem Land. Volume 1: Art, myth and symbolism, Melbourne University Press, Carlton, Vic., p. xxi.

11 Bonney, Director-General, Memorandum to The Secretary Department of Treasury, 1947, PublicityArnhem Land Expedition - C. P. Mountford, Series No. CP815/1-005.87, Part 1, National Archives of Australia (henceforth NAA), Canberra. 
I was called into the professor's office... and Wood said to me 'you won't be getting any payment, you'll get your travel and your keep, but you'd better go'...I had to prepare all this mountain of equipment to get away in January...By the time we'd got everything ready...I was informed that they were going to delay the expedition for a year...so everything went into chaos and I went back to teaching. ${ }^{12}$

The Expedition was delayed until March 1948 to allow completion of American research work in the Pacific, and to enable the Smithsonian to form a more representative and distinguished team of scientists. Norman McCrae, the Chief Administration Officer at the Department of Information, wrote to Specht in January 1948 with a formal offer for the position of botanist, at an annual salary of $£ 500$, on the understanding that Specht was already willing to accompany the Expedition and was qualified for the work. The letter of offer noted that work would commence on 1 February and finish at the end of November. ${ }^{13}$ Specht accepted the offer, formally joining the Expedition. The initial delay of the Expedition provided an opportunity for him to begin work on producing ecological maps of areas in northern Australia, drafted from aerial photographs. Mountford considered this to be valuable groundwork for the planning of research activities at each location to be visited. ${ }^{14}$

Three main camps were successively established across Arnhem Land, located in different types of landscape to maximise the diversity of scientific findings: Groote Eylandt, an island camp with stony hinterland; Yirrkala, on the coast; and Oenpelli (now Gunbalanya), with its stone country and floodplains, in Western Arnhem Land. As Charles Mountford wrote in his account of the Expedition, work for the botanist and other naturalists began after arriving in Darwin. During a 10-day delay prior to the Expedition party heading to Groote Eylandt, a sample of scientific specimens was collected along the coast and within the rainforest near Darwin. While working on Groote Eylandt, Raymond Specht collected and surveyed plants around the Umbakumba base camp and accompanied Margaret McArthur (nutritionist from the Australian Institute of Anatomy) to Bickerton Island to assist with nutritional studies and more botanical collecting. Yirrkala was an opportunity to collect along the coast, with its freshwater swamps and forests. At Oenpelli, Specht worked in open savannas, black-soil floodplains and sandstone plateau country. ${ }^{15}$

12 Specht, R. L. 2006, Oral history recording by Martin Thomas and Sally K. May, Oral TTC 5662, recorded 2 May 2006, National Library of Australia (henceforth NLA), Canberra.

13 N. McCrae to R. L. Specht, 21 January 1948, Publicity-Arnhem Land Expedition — Mountford, Series No. CP815/1-005.87, Part 1, NAA.

14 C. P. Mountford to Bonney, 6 February 1947, Publicity-Arnhem Land Expedition-C. P. Mountford, Series No. CP815/1-005.87, Part 1, NAA. 


\section{A Botanist Working in the Tropical North}

[I]t was interesting to land on Darwin aerodrome, because the tips of the wings [of the aeroplane] were touching this tall grass... as we landed. Interesting to an ecologist of southern Australia where nothing grows more than about a foot or two. ${ }^{16}$

The Arnhem Land Expedition was Raymond Specht's first visit to northern Australia. Drawing on his previous experience as a southern plant ecologist, he prepared the necessary equipment for collecting plant specimens, including such items as mountains of newspaper, plant presses, secateurs, compass, notebook, axe and backpack. For the Expedition, Specht's brother, Gordon, an apprentice sheetmetal worker, provided 12 sets of galvanised-steel plant presses. Refrigerator trays were used, as they were the same size as a folded broadsheet page of the Adelaide Advertiser newspaper. Plant specimens were placed on sheets of newspaper and securely pressed between two metal grids with leather straps. ${ }^{17}$

A typical day for the Expedition botanist commenced before breakfast, checking and drying plant specimens previously collected. Then, with axe over one shoulder and backpack over the other, he would head out to collect five new specimens before lunch and five before dinner. Where possible, the whole of the plant was collected, including the flowers, leaves, fruits and bark. Considering the requirement for 10 sets of each plant specimen collected, 100 specimens per day for processing was not unusual. Evenings were for pressing and drying the ever increasing botanical collection. ${ }^{18}$ Bessie Mountford would often help Specht change the papers for drying plants in the evenings. Diaries she kept about her experiences in Arnhem Land have many entries that mention these activities: 'After tea I helped Ray again with the paper changing... Ray has piles of specimens. He certainly is collecting as much as he possibly can. ${ }^{19}$

As Specht was to discover, there were some added challenges for the botanist working in a tropical environment. During the drying of the more succulent plants, newspaper sheets in presses needed to be changed every day. Mangroves and rainforest plants presented an added challenge to a botanist not experienced in collecting these types of plants from the field. They required a longer time to dry, coupled with an additional problem of leaves and flowers breaking off from the stems. Prior to joining the Expedition, Specht spent

16 Specht, Oral history recording, NLA.

17 Ibid.

18 Mountford, C. P. 1949, ‘Exploring Stone Age Arnhem Land', National Geographic, vol. 96, no. 5, p. 750.

19 Bessie Mountford, Unpublished diary 4, 1948 American-Australian Expedition to Arnhem Land, Entry written at Oenpelli 7 October 1948, PRG 487/1/2, Mountford-Sheard Collection, State Library of South Australia (henceforth SLSA). 
some time at the Queensland Herbarium in Brisbane acquainting himself with collection techniques and drying methods for tropical species. The herbarium staff recommended using an ordinary four-gallon drum filled with formalin to soak succulent plants for 24 hours, prior to placement in plant presses. This additional step solved the problem of leaves and flowers breaking off stems, ensuring that a respectable herbarium specimen was collected and preserved. With each day of collecting, it became necessary to counter longer drying times, as there was a steadily growing mountain of plants needing to be pressed. Prior to the Expedition, Raymond Specht and his brother devised another mechanism to assist in the drying of plant specimens: a drying oven. Specimens were put into the oven (a tank encased in a water jacket) and the unit was placed over a campfire. Drying time for plant specimens was significantly reduced-from 10-15 days to an average of three or four. ${ }^{20}$ Modifications in the processing and management of a growing botanical collection of tropical plants were integrated into the daily practice of the botanist. This was part of the challenge for Specht, working in a landscape unlike any he had encountered before.

Bickerton Island, west of Groote Eylandt, was a mix of mangrove swamp, eucalypt forest, black-soil plains and rocky tableland. Specht spent 21 days on the island and collected more than 200 plant specimens. A number of these were newly discovered species growing in rocky gorges and sandstone hills. At Yirrkala, another 288 species collected from along the coast, freshwater billabongs and eucalypt forests were added to the collection..$^{21}$ It was at Oenpelli, however, the final base camp, where botanical work proved most interesting. Mountford sent a telegram to the Department of Information stating: 'Expect Oenpelli to be rich field for all branches of scientific work for expedition stop rugged interior holds many rare specimens birds animals plants. ${ }^{22}$

The stone country where a number of unknown species flourished was of immense interest to Specht. ${ }^{23}$ He described the new plants in English and Latin, referring to field notes and the herbarium specimen. An example is Acacia mountfordiae, a species of wattle restricted to rocky sandstone habitat around Oenpelli. Specht named this plant after Bessie Mountford, following a request from Charles. There were also plant specimens collected earlier on the Expedition that were found growing in different environmental conditions at Oenpelli. ${ }^{24}$ These observations provided an opportunity for the botanist to begin thinking about another dimension of plant ecology: the history of changes in composition and distribution of Arnhem Land plant life over time and space.

\footnotetext{
20 Specht, Oral history recording.

21 Mountford, 'Exploring Stone Age Arnhem Land', p. 758.

22 C. P. Mountford, Telegram to the Department of Information, 14 September 1948, National Archives Publicity-Arnhem Land Expedition - C. P. Mountford, Series No. CP815/1-005.87, Part 3, NAA.

23 Mountford, 'Exploring Stone Age Arnhem Land', p. 778.

24 Bessie Mountford, Unpublished diary 4, Entry written at Oenpelli, 6 October 1948, Mountford-Sheard Collection, SLSA.
} 
Specht was very diligent in recording information for each specimen collected-13 500 in total. His Expedition field books listed a series of details including locality, habitat, life form (tree, shrub, herb, grass), date of collection, identification, and name of collector. There were additional notes on the colour and arrangement of leaves and flowers, and samples of bark taken from tree species. Every detail was needed, for, as Specht recalled, 'people might never have seen these things before' ${ }^{25}$

Over eight months, Specht created a comprehensive botanical collection, and detailed ecological surveys with what Bessie Mountford described as a 'quiet persistence and continued interest in his chosen career [that was] most commendable' ${ }^{26}$ Forty-two crates of botanical specimens were transported from Darwin to the Queensland Botanic Gardens in Brisbane at the end of the Expedition. ${ }^{27}$ The original collection was deposited in the Queensland Herbarium in Brisbane and replica sets went to institutions in Melbourne, Sydney, Canberra, Adelaide and Perth. Sets were also dispatched to Kew in the United Kingdom, Leiden in the Netherlands, and to the Arnold Arboretum and the Smithsonian Institution in the United States. Specht went to Brisbane for approximately five months to work in the Government Botanist's Office and complete work on the Arnhem Land collection. With assistance from a number of botanists from Australia and overseas, he completed identification of all the plant specimens. ${ }^{28}$

\section{Arnhem Land: A venue for science}

The idea of 'place' is central to Specht's work on the Expedition. Frank Vanclay defines three conditions that contribute to the idea of 'place': geographic location, physicality, and investment with meaning and value. ${ }^{29}$ As I will discuss, these factors are demonstrated in Specht's holistic approach to understanding the landscape, resulting in the creation of ecological surveys and vegetation maps of different study sites. In his published report, Specht illustrated the interrelationships between plant communities and other components of a dynamic ecosystem including climate, soil, bedrock and topography. ${ }^{30}$

\footnotetext{
25 Specht, Oral history recording.

26 Bessie Mountford, Unpublished diary 5, 1948 American-Australian Expedition to Arnhem Land, Entry written at Oenpelli 13 October 1948, Mountford-Sheard Collection, SLSA.

27 Publicity - Arnhem Land Expedition - C. P. Mountford, Series No. CP815/1-005.87, Part 3, NAA.

28 Mountford, C. P. and Specht, R. L. (eds) 1958, Records of the American-Australian Scientific Expedition to Arnhem Land. Volume 3: Botany and plant ecology, Melbourne University Press, Carlton, Vic., p. 185.

29 Vanclay, F. 2008, 'Place matters', in F. Vanclay, M. Higgins and A. Blackshaw (eds), Making Sense of Place: Exploring concepts and expressions of place through different senses and lenses, NMA Press, Canberra, pp. 3-11. 30 Mountford and Specht, Records of the American-Australian Scientific Expedition to Arnhem Land, vol. 3.
} 
During the Expedition, Specht wrote letters home to his family in Adelaide, describing features of the landscape in which he was working. Two examples illustrate the importance of understanding 'place' for the plant ecologist. The first letter provides a detailed description of the landscape as seen from the air:

[T] he Arnhem Land scarp was the most interesting part. Huge and majestic, distorted and writhing in agony as the sandstone had cracked apart when the earth bent under some gigantic strain, this geological formation appeared. Cracks that had been deepened into gorges with silver streams at their bases and waterfalls with spray rising high above them. Huge desolate crags, grand and beautiful in the early morning sunlight. Vegetation was confined to isolated cracks and crevices in which soil had collected. I am looking forward to visiting this country from Oenpelli. Then after 60-80 miles we flew over the backbone of Arnhem Land...This country is like Darwin with Darwin stringybarks, woollybutts and bloodwoods, red ironstone soil but not very much spear grass (due to lower rainfall?). A few wet swamps and streams looked remarkedly [sic] green from the air... and finally Blue Mud Bay. I often wondered why they dotted the coastline here (on maps), but now I know. There is a vast area of saltwater swamps behind, and, of course, the sea here is a real blue mud..$^{31}$

Specht makes sense of Arnhem Land unfolding below him as a function of time, geology and the dynamic nature of plant communities. He provides a geological location for this place in northern Australia. Attention to the physicality of the landscape is captured through his description of the dynamic nature of the Arnhem Land scarp, and the unique features found in this tropical landscape. This interpretation reflects his ecological training, taking a holistic approach to understanding the workings of Arnhem Land ecology.

A second letter provides a vivid description of another study site on the Expedition. Again, the botanist demonstrates his holistic understanding of place, interpreting changes in the structure and composition of plant communities in relation to different environmental features:

The majority of the area was stringybark savannah forest developed on an undulating ridge of truncated lateritic earth, with occasional outcrops of quartzite. A coastal sand-dune covered with grasses and an occasional bush and Pandanus ran alongside most of the $\mathrm{N}-\mathrm{S}$ beaches. Behind this, narrow belts of monsoon forest and paperbark swamps and billabongs occurred with a couple of streams lined with mangroves near their mouths. One paperbark lagoon impressed me beyond description.

31 R. L. Specht, Letter written home to family in Adelaide from Groote Eylandt, 11 April 1948. 
It was clothed in lots of blue waterlilies and green sedges...the beaches were sandy, lined with Casuarina and merged into either reef of lateritic slabs of quartzite or just sandy beach. ${ }^{32}$

For the Expedition botanist, a survey was recognised as more than just collecting and recording an inventory of Arnhem Land plants. Work also included an investigation into the dynamics of plant communities growing in unique environmental conditions including sandstone hills, freshwater billabongs, undulating plains and extensive floodplains (see Figure 8.1). Specht's letters about the landscape reveal an increasing familiarity with Arnhem Land through an active engagement with the locations visited. It is exactly the kind of engagement that Jeff Malpas suggests develops a sense of place. ${ }^{33}$

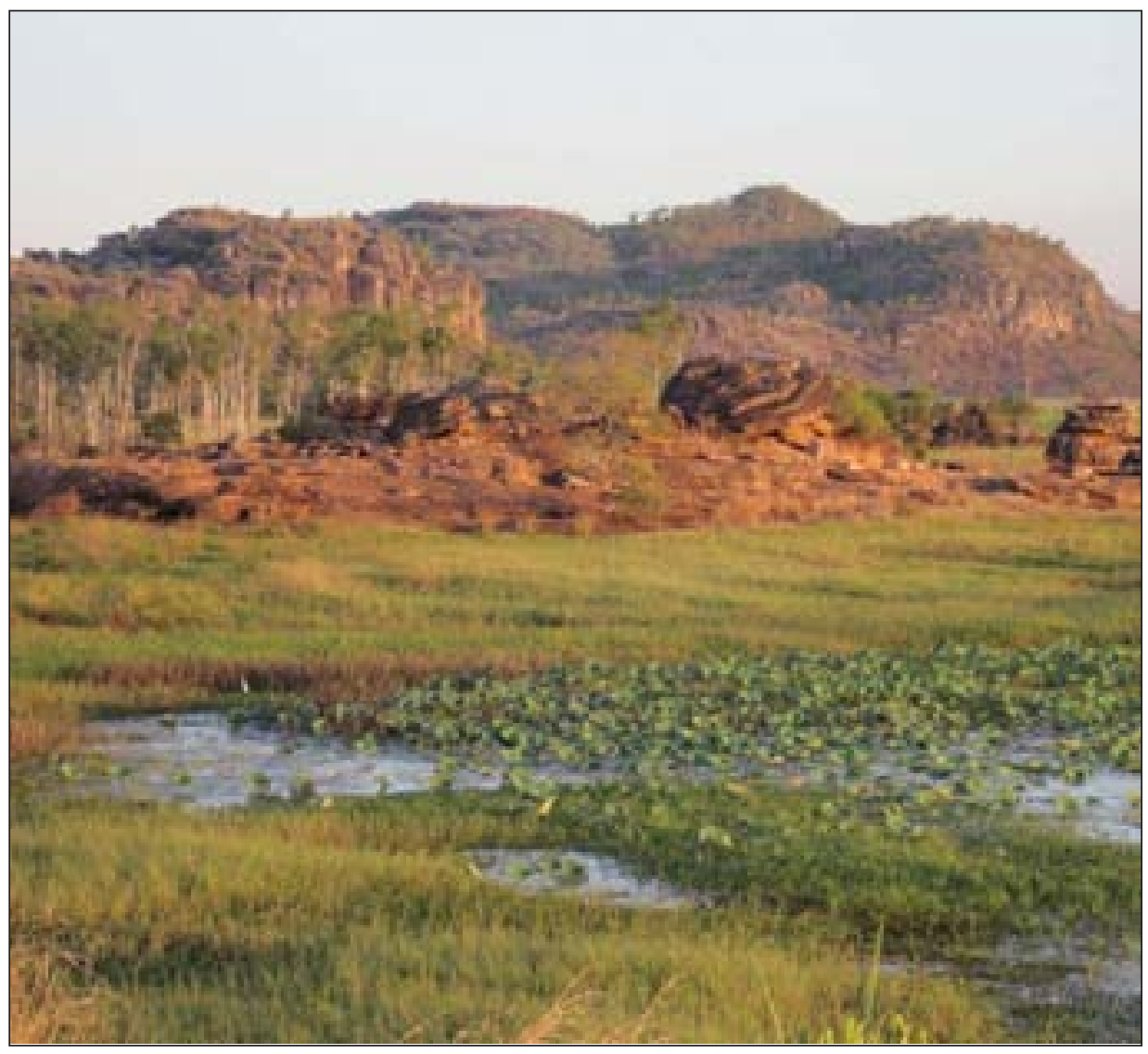

Figure 8.1 Western Arnhem Land near Gunbalanya (formerly Oenpelli), 2009

Photograph by Lynne McCarthy

32 R. L. Specht, Letter written home to family in Adelaide from Umbakumba, Groote Eylandt, 17 May 1948.

33 Malpas, J. 2008, 'Place and human being', in Vanclay et al., Making Sense of Place, pp. 325-31. 


\section{A Living Collection}

The botanical collections from the Expedition are of national and international significance. The collection is a diverse and rich assemblage of Arnhem Land flora that includes specimens of fungi, moss, lichen, ferns, algae (freshwater and marine), gymnosperms (non-flowering plants), and flowering plants. The collection included newly discovered species and new varieties of plants.

Sixty years after the Expedition, scientific research into the ecological workings of the tropical north continues. ${ }^{34}$ Raymond Specht's work has been referred to as the earliest comprehensive description of flora from Arnhem Land, providing a valuable resource for continuing research across northern Australia including extensive surveys of plant communities, fire management, biodiversity studies, and vegetation-mapping projects. Specht's oral history in this volume - providing an insider's perspective on the legacy of the Arnhem Land Expedition - highlights the fact that many of the ecological questions he posed at the time formed the basis for his continuing national and international research as a plant ecologist. Species composition, structure and the formation of plant communities growing in different environmental conditions and locations could be further investigated through the analysis of the comprehensive botanical collections generated from his Arnhem Land fieldwork.

Individual specimens from the collection have been reviewed, reclassified and in some instances renamed. Some herbarium specimens now carry additional labels and annotations from recent botanists working with the collection, outlining changes to accepted scientific names and classification (see Figure 8.2). Specht named the plant shown in Figure 8.2 for his wife Marion, choosing magnifica to describe the most magnificent flower collected during the Expedition. In the Queensland Herbarium, the newly rediscovered plant specimens from 1948the majority of which were collected from Bickerton Island and Oenpelli-are stored in a fire- and bomb-proof room within the main herbarium holdings (see Figure 8.3). This is testimony to the national significance of this botanical collection, ensuring secure storage and access to researchers for many years to come.

34 Woinarski, J., Mackey, B., Nix, H. and Traill, B. 2007, The Nature of Northern Australia: Natural values, ecological processes and future prospects, ANU E Press, Canberra. 


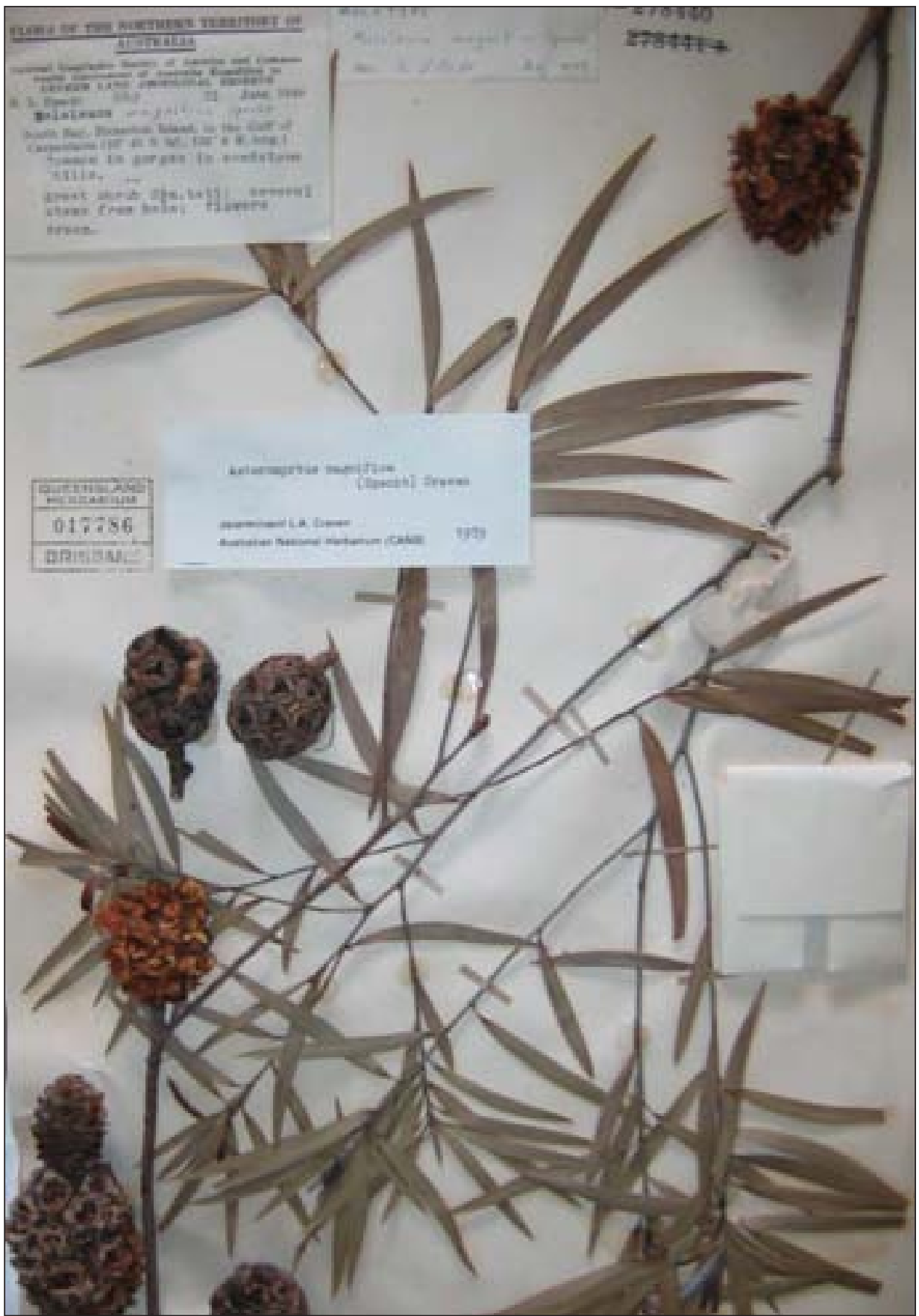

Figure 8.2 Herbarium specimen Melaleuca magnifica collected from Bickerton Bay

Photograph by Lynne McCarthy, 2009. By permission of Queensland Herbarium, Brisbane Botanic Gardens Mt Coot-tha. American-Australian Scientific Expedition to Arnhem Land Collection. 


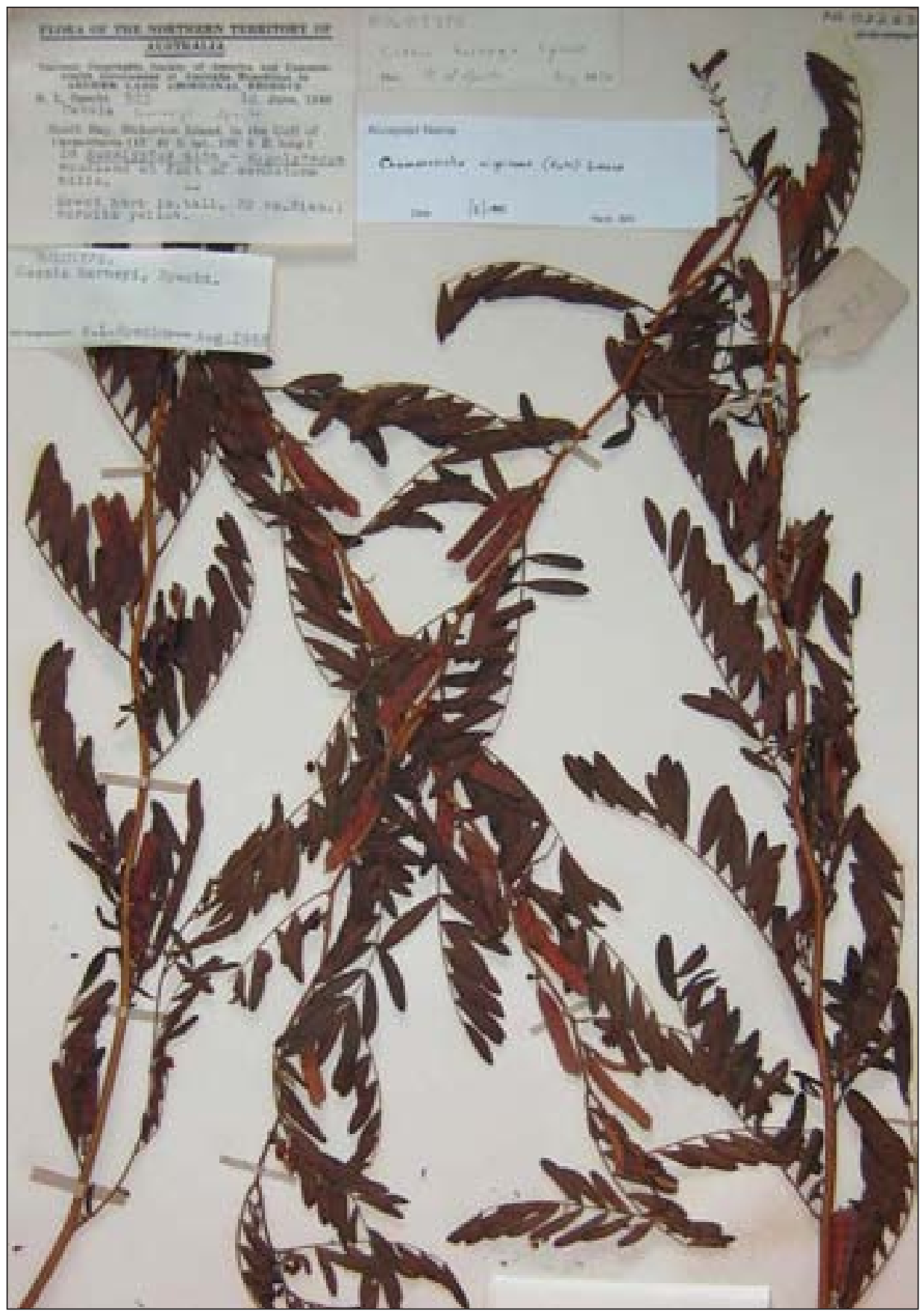

Figure 8.3 Herbarium specimen Cassia harneyi collected from Bickerton Island

Photograph by Lynne McCarthy, 2009. By permission of Queensland Herbarium, Brisbane Botanic Gardens Mt Coot-tha. American-Australian Scientific Expedition to Arnhem Land Collection. 


\section{Concluding Remarks}

For Raymond Specht - a young plant ecologist from southern Australiathe role of botanist on the Arnhem Land Expedition was an exciting and challenging prospect. A comprehensive botanical collection of 13500 specimens and ecological surveys and vegetation maps provided the groundwork for investigations into the ecology of Arnhem Land plant communities. His skill, dedication and passion for fieldwork were driving forces in the completion of a significant body of work on the botany and plant ecology of Arnhem Land. The Expedition botanist embraced his work in northern Australia, maintaining a holistic approach to understanding the ecology of tropical landscapes. 